\title{
ANALISIS FENOMENA DIARE AKUT PADA BALITA 6-24 BULAN TERHADAP KONSUMSI ASI DAN MP-ASI DI PUSKESMAS SAMBAS KECAMATAN SIBOLGA KOTA, KOTA SIBOLGA, SUMATERA UTARA TAHUN 2020
}

\author{
Muhammad Syahrullah Pohan ${ }^{1}$, Natassha Millenizkha Hillary Nada Silalahi \\ Muhammad Aditya Kurnia ${ }^{3}$ \\ 1,2,3Program Studi Pendidikan Dokter, Fakultas Kedokteran, Universitas Prima Indonesia \\ Rullahpohan1@gmail.com
}

\begin{abstract}
Abstrak
Penyebab Diare akut pada anak erat kaitannya dengan faktor lingkungan dan faktor perilaku. Faktor lingkungan yaitu yang disebabkan oleh sejumlah bakteri, virus dan organisme parasit, yang sebagian besar disebarkan oleh air yang terkontaminasi faeces. Penelitian ini menggunakan metode analitik observasional dengan desain penelitian cross sectional, dengan metode purposive sampling sebagai teknik pengambilan sampel. Hasil penelitian menunjukkan bahwa paling banyak balita jenis kelamin paling banyak adalah laki-laki (51\%), mayoritas berusia 7-12 bulan (37\%), lama diare mayoritas 3-4 hari (48\%), frekuensi diare sebanyak 1-3 kali/ hari sebanyak (54\%), konsistensi lembek sebanyak (60\%), berdasarkan pemberian ASI pada balita paling banyak ibu memberikan ASI kepada anaknya sebanyak (55\%), usia MPASI paling banyak diberikan pada usia 7 bulan (67\%), Berdasarkan usia MPASI paling banyak anak diberikan sebanyak 2-3 kali/hari sebanyak (70\%). Ada hubungan yang signifikan pemberian ASI $(p=0,046)$ dan MP-ASI $(p=0,015)$ dengan kejadian diare akut pada balita usia 6-24 Bulan di Puskemas Sambas.
\end{abstract}

Kata Kunci : Diare Akut, MP-ASI, ASI

\begin{abstract}
The causes of acute illness in children are closely related to environmental and behavioral factors. Environmental factors are caused by a number of bacteria, viruses and parasitic organisms, most of which are spread by fecal contaminated air. This study used an observational analytic method with a cross sectional study design, with a purposive sampling method as a sampling technique. The results showed that the most children under five were male (51\%), aged 7-12 months (37\%), diarrhea duration was around 3-4 days (48\%), diarrhea frequency was 1-3 times / days (54\%), flaccid consistency (60\%), based on offering breast milk to toddlers, the most mothers gave breast milk to their children (55\%), the most MPASI age was given at 7 months (67\%). At most, complementary foods are given 2-3 times / day (70\%). There was a significant correlation between offering ASI ( $p=0.046)$ and complementary feeding $(p=0.015)$ with the incidence of acute diarrhea in children aged 6-24 months at Puskemas Sambas.
\end{abstract}

Keywords: Acute diarrhea, MP-ASI, ASI 


\section{PENDAHULUAN}

Diare akut adalah kondisi dimana frekuensi buang air besar lebih dari $4 x$ pada bayi dan lebih dari $3 x$ pada anak dalam satu hari dengan konsistensi cair, lembek, terdapat lendir atau darah dalam faeces yang menyebabkan hilangnya cairan dan elektrolit yang kurang dari 14 hari $^{(1)}$.

Penyebab Diare akut pada anak erat kaitannya dengan faktor lingkungan dan faktor perilaku. Faktor lingkungan yaitu yang disebabkan oleh sejumlah bakteri, virus dan organisme parasit, yang sebagian besar disebarkan oleh air yang terkontaminasi faeces. Infeksi lebih sering terjadi ketika ada kekurangan sanitasi dan kebersihan yang memadai dan air yang aman untuk minum, memasak dan membersihkan. Rotavirus dan Escherichia coli adalah dua agen penyebab yang paling umum dari diare di negara-negara berpenghasilan rendah. Patogen lain seperti cryptosporidium dan spesies shigella juga menjadi penyebab terjadinya Diare. Lingkungan dimana anak tinggal juga perlu dipertimbangkan ${ }^{(2)}$.

Faktor perilaku yang menyebabkan terjadinya diare yaitu tidak memberikan ASI ekslusif secara penuh pada bulan pertama kehidupan, tidak mencuci bersih botol susu anak, penyimpanan makanan yang salah, menggunakan air minum yang tercemar, tidak mencuci tangan pada saat memasak, makan, sebelum menyuapi anak, sesudah buang air besar, sesudah membuang tinja anak, dan tidak membuang tinja dengan benar. Kemudian faktor lingkungan, yaitu sarana air bersih dan pembuangan tinja. Kedua faktor ini berhubungan dengan perilaku manusia ${ }^{(3)}$.

Teknik pencegahan diare akut pada anak ada beberapa teknik, termasuk kebersihan dan sanitasi, diet, obat-obatan dan suplemen yang umumnya diklasifikasikan sebagai perawatan kesehatan, menyusui dan probiotik $^{(4)}$. Penyakit diare merupakan masalah kesehatan masyarakat dibanyak wilayah didunia, pada tahun 2017, diare menjadi penyebab kematian sekitar 480.000 anak kecil di seluruh dunia, 8 persen dari semua kematian terjadi diantara anak-anak di bawah usia 5. Sebagian besar kematian akibat diare terjadi di antara anak-anak di bawah usia 2 yang tinggal di Asia Selatan atau Afrika subSahara, mencatat 1,7 milyar orang meninggal setiap tahun karena penyakit diare ${ }^{(5),(6),(7)}$.

Data nasional menyebutkan bahwa prevalensi Diare di Indonesia saat ini adalah 3,5\% lebih kecil dari Riskesdas 2014 yaitu 9\%. Insiden diare di Indonesia untuk seluruh kelompok umur di Indonesia adalah 3,5\%. Lima provinsi dengan insiden dan prevalen diare tertinggi adalah Papua (6,3\% dan 14,7\%), Sulawesi Selatan $15,2 \%$ dan $10,2 \%)$, Aceh (5\% dan 9,3\%), Sulawesi Barat $(4,7 \%$ dan 10,1\%) dan Sulawesi Tengah (4,4\% dan 8,8\%) (Riset Kesehatan Dasar. ${ }^{(8)}$

Di Provinsi Sumatera Utara, total kasus kematian bayi pada tahun 2018 yang disebabkan oleh diare adalah sebanyak 4,6\%. ${ }^{\text {(9) }}$ Pada tahun 2017 di Sumatera Utara, diperkiraan terdapat 180.777 kasus diare yang ditemukan dan ditangani, atau sebear $23,45 \%$ dari target penemuan kasus. Capaian ini mengalami penurunan bila dibandingkan dengan tahun 2016 dari target penemuan kasus sebesar 761.557 kasus, yang ditemukan dan ditangani sebesar 235.495 kasus (30,92\%). Dari 33 kabupaten/kota yang ada, penemuan dan penanganan kasus diare tertinggi di 3 (tiga) kabupaten/kota yaitu Kabupaten Samosir (58,87\%), Kota Sibolga (50,80\%), dan Kabupaten Padang Lawas Utara $(47,69 \%)$. Sedangkan penemuan dan penanganan kasus diare terendah di Kabupaten Nias Barat (2,87 \%), Kabupaten Padang Lawas (4,32 \%) dan Kabupaten Nias (8,97\%). Diare pada anak memiliki hubungan dengan pemberian ASI dan MPASI. Manfaat dari pemberian ASI eksklusif diketahui memiliki banyak manfaat bagi pertumbuhan bayi, tetapi kenyataannya, masih banyak yang belum memberikan ASI eksklusif. Pada tahun 2013, pemberian ASI eksklusif di Indonesia sebesar 54,3\% atau sebanyak 1.348 .532 bayi, sedangkan pemberian ASI yang tidak eksklusif 1.134 .952 bayi. ${ }^{(10)}$

Pencegahan sederhana yang dapat dilakukan adalah dengan mencuci tangan menggunakan sabun dan dengan air yang mengalir ketikan ingin memberi ASI atau makanan kepada anak. ${ }^{(11)}$ Pemberian makanan untuk bayi yang baik dan optimal adalah pemberian ASI (air susu ibu) sampai 6 bulan. Kemudian diikuti dengan pemberian makanan pendamping air susu ibu (MPASI) tetapi pemberian ASI tetap dilanjutkan sampai usia 2 tahun, hal ini dikarenakan pemberikan ASI saja tidak mencukupi kebutuhan energi anak. ${ }^{(12)}$

Bayi yang telah diberi MP-ASI sejak dini menyebabkan kebutuhan untuk mengonsumsi ASI akan berkurang dari sebelumnya sehingga produksi ASI akan menurun. Dengan berkurangnya frekuensi ASI yang diminum oleh bayi maka otomatis nutrisi dari ASI yang biasanya mencukupi kebutuhan bayi akan berkurang dan dapat menurunkan sistem imunitas anak. Menurunnya sistem imunitas anak akan menyebabkan anak mudah terserang penyakit, diantaranya gangguan saluran cerna yaitu diare. 


\section{METODE}

Penelitian ini menggunakan metode analitik observasional dengan desain penelitian cross sectional, dengan metode purposive sampling sebagai teknik pengambilan sampel. Penelitian dilaksanakan di Puskesmas Sambas, Kecamatan Sibolga Kota, Kota Sibolga, Sumatera Utara. Waktu penelitian ini dari bulan Mei sampai dengan Juli 2020. Sampel ialah bagian dari populasi yang diambil dengan menggunakan cara-cara tertentu dan karakteristiknya dianggap mewakili seluruh populasi, Teknik sampling yang digunakan dalam penelitian ini adalah purposive sampling. Setelah didapatkan data diare akut terhadap balita 6-24 bulan, kemudian dilakukan olah data menggunakan lewat SPSS dengan menggunakan uji chi square

HASIL

Tabel 1 Data Kunjungan Pasien Diare Akut Pada Balita 6-24 Bulan di Puskesmas Sambas Periode Januari -Mei 2020

\begin{tabular}{lcc}
\hline \multicolumn{1}{c}{ Variabel } & Frekuensi & Persentase \\
\hline Januari & 22 & 22.9 \\
\hline Februari & 18 & 18.7 \\
\hline Maret & 15 & 15.6 \\
\hline April & 14 & 14.6 \\
\hline Mei & 27 & 28.2 \\
\hline Total & 96 & 100 \\
\hline
\end{tabular}

Berdasarkan tabel 1 menyatakan bahwa paling banyak pasien diare akut pada balita 6-24 bulan di Puskesmas Sambas pada bulan Mei 27 orang $(28 \%)$, Januaro 22 orang (23\%), Februari 18 orang (19\%), Maret 15 orang (15\%), dan April sebanyak 14 orang (14\%). Data pasien didapati nilai rata-rata 19 orang setiap bulannya.

Tabel 4.2 Distribusi Frekuensi Berdasarkan Usia Pada Balita 6-24 Bulan di Puskesmas Sambas

\begin{tabular}{lcccc}
\hline Variabel & Frekuensi & $\begin{array}{c}\text { Persentas } \\
\text { e }\end{array}$ & Mean & SD \\
\hline Usia & & & & \\
\hline $\begin{array}{l}\text { 1-6 bulan } \\
7-12\end{array}$ & 14 & 14.6 & 2.52 & 0.96 \\
bulan & 36 & 37.5 & & \\
\hline $\begin{array}{l}13-18 \\
\text { bulan }\end{array}$ & 28 & 29.2 & & \\
\hline $\begin{array}{l}19-24 \\
\text { bulan }\end{array}$ & 18 & 18.8 & & \\
\hline Total & 96 & 100 & & \\
\hline
\end{tabular}

Berdasarkan tabel 4.2 menyatakan bahwausia paling banyak berusia 7-12 bulan sebanyak 36 orang (37\%), usia $13-18$ bulan sebanyak 28 orang (29\%), usia 19-24 bulan sebanyak 18 orang (18\%), dan yang berusia 1-6 bulan sebanyak 14 orang (14\%). Nilai rerata $2.52 \pm 0.962$ SD. Hasil penelitian menunjukkan bahwa paling banyak balita yang berusia 7-12 bulan dan paling sedikit pada usia 1-6 bulan.

Tabel 3 Distribusi Frekuensi Berdasarkan Jenis Kelamin Pada Balita 6-24 Bulan di Puskesmas Sambas

\begin{tabular}{lllll}
\hline Variabel & Frekuensi & Presentase & Mean & SD \\
\hline $\begin{array}{l}\text { Jenis } \\
\text { Kelamin }\end{array}$ & & & & \\
\hline Laki-laki & 49 & 51 & 1.49 & 0.503 \\
\hline Perempuan & 47 & 49 & & \\
\hline Total & 96 & 100 & & \\
\hline
\end{tabular}

Berdasarkan tabel 3 menyatakan bahwa jenis kelamin paling banyak adalah laki-laki sebanyak 49 orang (51\%) dan perempuan sebanyak 47 orang (49\%).Nilai rerata dijumpai $1.49 \pm 0.503$ SD. Kecamatan Sibolga Kota merupakan kecamatan yang letaknya tepat di pusat kota Sibolga dengan jumlah penduduk sebanyak 14.279 jiwa.

Tabel 4 Distribusi Frekuensi Berdasarkan Lama Diare Pada Balita 6-24 Bulan di Puskesmas Sambas

\begin{tabular}{lcccc}
\hline $\begin{array}{l}\text { Lama } \\
\text { Diare }\end{array}$ & Frekuensi & Persentase & Mean & SD \\
\hline 1-2 hari & 45 & 46.9 & 1.58 & 0.592 \\
\hline 3-4 hari & 46 & 47.9 & & \\
\hline 5-6 hari & 5 & 5.2 & & \\
\hline Total & 96 & 100 & & \\
\hline
\end{tabular}

Berdasarkan tabel 4 menyatakan bahwa paling banyak balita dengan lama diare selama 3-4 hari sebanyak 6 orang (48\%), selama $1-2$ hari sebanyak 45 orang $(47 \%)$, selama 5-6 hari sebanyak 5 orang (5\%). Nilai rerata $1.58 \pm 0.592$ SD. Menurut Kemenkes (2011) menyatakan bahwa Penyebab kematian bayi (usia 29 hari -11 bulan) yang terbanyak adalah diare $(31,4 \%)$.

Tabel 5 Distribusi Frekuensi Berdasarkan Frekuensi Diare Pada Balita 6-24 Bulan di Puskesmas Sambas

\begin{tabular}{lcccc}
\hline $\begin{array}{l}\text { Frekuensi } \\
\text { Diare }\end{array}$ & Frekuensi & Persentase & Mean & SD \\
\hline $\begin{array}{l}1-3 \\
\text { kali/hari }\end{array}$ & 52 & 54.2 & 1.46 & 0.501 \\
\hline $\begin{array}{l}4-6 \\
\text { kali/hari }\end{array}$ & 44 & 45.8 & & \\
\hline Total & 96 & 100 & & \\
\hline
\end{tabular}

Berdasarkan tabel 5 menyatakan bahwa frekuensi diare sebanyak 1-3 kali/ hari sebanyak 52 orang (54\%) dan sebanyak 4-6 kali/ hari sebanyak 44 orang (46\%). Nilai rerata $1.46 \pm 0.501$ SD. 
Tabel 6 Distribusi Frekuensi Berdasarkan Konsistensi Diare Pada Balita 6-24 Bulan di Puskesmas Sambas

\begin{tabular}{|c|c|c|c|c|}
\hline $\begin{array}{c}\text { Konsisten } \\
\text { si } \\
\text { Diare } \\
\end{array}$ & Frekuensi & Persentase & Mean & SD \\
\hline Cair & 58 & 60.4 & 1.40 & $\begin{array}{r}0.4 \\
92 \\
\end{array}$ \\
\hline Lembek & 38 & \multicolumn{2}{|l|}{39.6} & \\
\hline Total & 96 & \multicolumn{2}{|l|}{100} & \\
\hline \multicolumn{5}{|c|}{$\begin{array}{l}\text { Berdasarkan tabel } 6 \text { menyatakan bahwa konsistensi } \\
\text { paling banyak dengan konsistensi lembek sebanyak } \\
58 \text { orang ( } 60 \%) \text { dan konsistensi cair sebanyak } 38 \\
\text { orang (39\%). Nilai rerata dijumpai } 1,40 \pm 0,492 \text { SD. }\end{array}$} \\
\hline \multicolumn{5}{|c|}{$\begin{array}{l}\text { Pemberian ASI Pada Balita 6-24 Bulan di } \\
\text { Puskesmas Sambas }\end{array}$} \\
\hline $\begin{array}{l}\text { Pemberian } \\
\text { ASI }\end{array}$ & Frekuensi & Presentase & Mean & SD \\
\hline Ya & 53 & 55.2 & 1.55 & 0.500 \\
\hline Tidak & 43 & 44.8 & & \\
\hline Total & 96 & 100 & & \\
\hline
\end{tabular}

Berdasarkan tabel 7 menyatakan bahwa pemberian ASI pada balita paling banyak ibu memberikan ASI kepada anaknya sebanyak 53 orang (55\%) dan tidak memberikan ASI sebanyak 43 orang (45\%). Dijumpai nilai rerata 1,55 $\pm 0,500$ SD.

Tabel 8. Distribusi Frekuensi Berdasarkan Usia MPASI Pada Balita 6-24 Bulan di Puskesmas Sambas

\begin{tabular}{|c|c|c|c|c|}
\hline $\begin{array}{l}\text { Usia } \\
\text { MP-ASI }\end{array}$ & Frekuensi & Persentase & Mean & SD \\
\hline 5 bulan & 6 & 6.2 & 2.61 & 0.605 \\
\hline 6 bulan & 65 & 67.7 & & \\
\hline 7 bulan & 25 & 26 & & \\
\hline Total & 96 & 100 & & \\
\hline \multicolumn{5}{|c|}{$\begin{array}{l}\text { Berdasarkan tabel } 8 \text { menyatakan bahy } \\
\text { MP-ASI paling banyak diberikan pada usia } \\
\text { sebanyak } 25 \text { orang }(26 \%), 6 \text { bulan seban } \\
\text { orang ( } 67.7 \% \text { ) dan selama } 5 \text { bulan sebanyak } \\
\text { (6\%).Dijumpai nilai rerata } 2.61 \pm 0,605 \text { SD. } \\
\text { Tabel.9 Distribusi Frekuensi Berdasarkan Fre } \\
\text { MP-ASI Pada Balita } 6-24 \text { Bu } \\
\text { Puskesmas Sambas }\end{array}$} \\
\hline $\begin{array}{l}\text { Frekuensi } \\
\text { MP-ASI }\end{array}$ & Frekuensi & Persentase & Mean & SD \\
\hline 1 kali/hari & 28 & 29.2 & 1.71 & 0,457 \\
\hline 2-3kali/hari & 68 & 70.8 & & \\
\hline Total & 96 & 100 & & \\
\hline
\end{tabular}

Berdasarkan tabel 9 menyatakan bahwa usia MPASI paling banyak anak diberikan sebanyak 2-3 kali/hari sebanyak 68 orang (70\%), dan sebanyak 1 $\mathrm{kal} /$ harisebanyak $28 \quad$ orang

dijumpainilairerata $1,71 \pm 0,457$ SD

Tabel 10 Hubungan Pemberian ASI dan MP-ASI dengan Kejadian Diare Akut Pada BalitaUsia 6-24 Bulan di Puskemas Sambas

\begin{tabular}{ll}
\hline Variabel & Nilai $\mathbf{p}$ \\
\hline Pemberian & \\
ASI*KejadianDiare & 0.046 \\
\hline Pemberian MP- & \\
ASI*KejadianDiare & 0.015 \\
\hline
\end{tabular}

Berdasarkan tabel 10 menyatakan bahwa hasil analisis uji chi square pada variable pemberian ASI dengan kejadian diare didapati nilai p 0,046 yang menyatakan bahwa ada hubungan yang signifikan antara pemberian ASI dengan kejadian diare akut pada balita usia 6-24 bulan di Puskemas Sambas. Hasil analisis uji chi square pada variable pemberian ASI dengan kejadian diare didapati nilai p 0,015 yang menyatakan bahwa ada hubungan yang signifikan antara pemberian MP-ASI dengan kejadian diare akut pada balita usia 6-24 bulan di Puskemas Sambas.

\section{DISKUSI}

Hasil penelitian yang dilakukan pada 96 orang Balita menyatakan bahwa adanya hubungan pemberian ASI dan MP-ASI dengan kejadian diare akut di Puskemas Sambas. Hasil penelitian ini didukung oleh penelitian Hapilah yang menyatakan bahwa dari 55 sampel diketahui bahwa anak yang diberi ASI eksklusif dan mengalami diare akut sebanyak 3 anak (12,5\%), sedangkan anak yang PASI dan mengalami diare akut sebanyak 21 anak (87,5\%). Adapun anak yang diberi ASI Eksklusif dan tidak mengalami diare akut sebanyak 22 anak (71,0\%), sedangkan anak yang diberi PASI dan tidak mengalami diare akut sebanyak 9 anak (29\%). Hasil uji statistic dengan uji Chi Square diperoleh nilai $\mathrm{P}=$ $0,000, P<0,05$ yang berarti terdapat perbedaan yang bermakna. Kejadian diare akut pada anak yang diberi ASI eksklusif lebih sedikit disbanding anak yang diberi PASI ${ }^{(13)}$

Hasil penelitian ini sesuai dengan penelitian Ningsih (2016) yang menyatakan bahwa ada hubungan pemberian ASI, pekerjaan ibu, status gizi bayi dengan kejadian diare pada bayi. Pemberian ASI faktor paling berpengaruh dengan kejadian diare pada bayi. Pemberian ASI menurunkan kejadian diare pada bayi ${ }^{(14)}$.

Hasil penelitian ini didukung oleh penelitian Andriana (2010) tentang hubungan pemberian makanan pendamping ASI (MP-ASI) 
dengan kejadian diare pada bayi usia< 6 bulan di Desa Koto Tinggi Wilayah Kerja Puskesmas Rambah, terdapat hubungan antara pemberian MP-ASI dengan kejadian diare dengan nilai $p$ - value $=0,007$. Penelitian lain juga yang dilakukan oleh Maryanto (2013) tentang hubungan pemberian MP-ASI dengan kejadian diare pada bayi umur 0-6 bulan di Desa Bancak Kabupaten Semarang, didapatkan nilai $p$-value $=0,023$ yang berarti ada hubungan antara pemberian MP-ASI dengan kejadian diare ${ }^{(15)}$.

Berdasarkan hasil penelitian alasan responden mengapa anaknya terserang diare karena memberikan MP-ASI pada bayi di usia $<6$ bulan, disamping itu kurangnya ibu memperhatikan kebersihan dot botol tempat susu bayi, serta kebiasaan dan pola makan anak yang tidak sesuai menyebabkan anak menjadi rentan terserang penyakit. Pengkategorian praktek MP ASI yang baik pada penelitian ini mengacu pada 7 Prinsip Utama Makanan Pendamping ASI Menurut Standar WHO tahun 2005 yaitu pemberian MP ASI yang dilakukan ibu dengan higienitas yang baik yaitu mencuci dan atau merebus alat makan terlebih dahulu sebelum memeberikan makanan pada anak, frekuensi sesuai dengan anjuran WHO yaitu pada awal MPASI usia 6 bulan, frekuensi makan diberikan dua kali.

Pada umur 6-9 bulan, frekuensi MPASI diberikan 3 kali. Berikan snack biscuit atau buah matang1-2 kali sehari. Pada umur 9-11 bulan, frekuensi MPASI diberikan 4 kali sehari. Berikan snack 1-2 kali sehari. Pada umur 12-24 bulan, frekuensi makan diberikan 5 kali sehari dan juga snack tambahan. Cara pemberian MP ASI yang baik dan benaryaitu Pada awal MPASI jumlah makanan yang diberikan sekitar 2-3 sendok makan dewasa. Usia 6-9 bulan menjadi $1 / 2$ cangkir, Usia 9-11 bulan menjadi $3 / 4$ cangkir dan Usia 12- 24 menjadi 1 cangkir penuh. Tekstur makanan yang tepat yaitu usia 6 bulan (bubur saring, pure atau makanan yang ditumbuk/dihaluskan). Perlu dipastikan makanan tidak terlalu cair sehingga gunakan sedikit saja air, Usia 8 bulan sudah dapat dikenalkan dengan finger food seperti kentang rebus, ketela atau buahbuahan. Umur 9-11 bulan tekstur naik menjadi makanan lembek (nasi tim, bubur tanpa saringan atau makanan yang dicincang halus) dan Umur 12 bulan bayi sudah dapat makan makanan keluarga. ${ }^{(17)}$

Selanjutnya hasil penelitian Aditya Sasongko (2012) tentang hubungan pemberian MPASI dengan kejadian diare pada bayi umur 0-6 bulan di Kecamatan Pedan Kabupaten Klaten, didapatkan nilai $p$ - value $=0,020$ yang berarti ada hubungan antara pemberian MP-ASI dengan kejadian diare.
Hasil analisa peneliti untuk responden yang diberi MP-ASI dan tidak mengalami diare, hal ini mungkin disebabkan karena ibu berpendidikan menengah dan tinggi (SMA, SMK, PT), secara umum semakin tinggi tingkat pendidikan seseorang maka semakin banyak pengetahuan dan informasi yang bias diterima, hal ini akan mempengaruhi perilaku ibu dalam memberikan makanan pendamping ASI (MPASI) pada bayi/balita yaitu dengan cara diberikan pada waktu yang tepat, usia, frekuensi, porsi, cara pemberian dan jenis makanan pendampingnya sesuai dengan ketentuan, seperti MP-ASI diberikan ketika bayi sudah berusia lebih dari 6 bulan dikarenakan system pencernaan pada anak usia setelah enam bulan sudah dapat menerima asupan makanan dengan baik, frekuensi pemberian MP-ASI nya sudah baik tidak berlebihan seperti MP-ASI diberikan 3 kali sehari, diberikan dengan porsi yang tepat pada setiap kali makan yaitu dengan jumlah takaran makan sesuai dengan usia anak dan MP-ASI diberikan dengan cara yang baik dan benar seperti mencuci tangan sebelum menyentuh makanan, mencuci bahan makanan dan peralatan makan dengan bersih, menyajikan makanan dengan baik. Begitu juga berdasarkan analisa peneliti untuk responden yang tidak diberi MP-ASI dan mengalami diare, hal ini mungkin terjadi karena ibu kurang memperhatikan dalam jenis makanan, porsi makanan tidak sesuai atau diberikan secara berlebihan, frekuensi makan lebih dari 3 kali, jenis makanan tidak sesuai dengan usia bayi atau dalam menyajikan makanan kurang terjaga, kebersihan cara penyimpanan yang kurang baik (terbuka) sehingga makanan terkontaminasi oleh bakteri juga merupakan penyebab diare ${ }^{(16)}$.

Makanan pendamping ASI (MP-ASI) berpengaruh terhadap kejadian diare. Ibu-ibu diWilayah Kerja Puskesmas Sambas Sibolga hal ini terjadi karena ibu menganggap bila bayinya menangis bayi lapar dan perlu member tambahan MP-ASI dan ibu menganggap bahwa ASI saja tidak cukup untuk kebutuhannya, ibu juga merasa lebih tenang bila bayinya kenyang dan tidak rewel. Ibu juga tidak tahu akibat pemberian MP-ASI terlalu dini. Padahal ASI saja sudah merupakan makanan yang baik untuk bayi karena komponen zat makanan tersedia dalam bentuk yang ideal dan seimbang untuk dicerna dan diserap secara optimal oleh bayi. ASI saja sudah cukup untuk memenuhi kebutuhan pertumbuhan bayi sampai umur 4-6 bulan. 


\section{SIMPULAN}

1. Berdasarkan jenis kelamin paling banyak balita jenis kelamin paling banyak adalah laki-laki (51\%)

2. Berdasarkan usia paling banyak berusia 7-12 bulan (37\%),

3. Berdasarkan lama diare paling banyak berusia 34 hari (48\%)

4. Berdasarkan frekuensi diare sebanyak 1-3 kali/ hari sebanyak (54\%)

5. Berdasarkan konsistensi paling banyak dengan konsistensi lembek sebanyak (60\%)

6. Berdasarkan pemberian ASI pada balita paling banyak ibu memberikan ASI kepada anaknya sebanyak (55\%) dan

7. Berdasarkan usia MPASI paling banyak diberikan pada usia 7 bulan (67\%),

8. Berdasarkan usia MPASI paling banyak anak diberikan sebanyak 2-3 kali/hari sebanyak (70\%).

9. Ada hubungan yang signifikan pemberian ASI $(p=0,046)$ dan MP-ASI $(p=0,015)$ dengan

\section{DAFTAR PUSTAKA}

1. Depkes RI. Lima langkah tuntaskan diare. Dep Kesehat RI. 2011;

2. WHO. Diarrhoeal disease. World Health Organization. 2017.

3. Chidziwisano K, Slekiene J, Mosler H, Morse T. Improving Complementary Food Hygiene Behaviors Using the Risk, Attitude, Norms , Ability, and Self-Regulation Approach in Rural Malawi. 2020;

4. M. Khalili, M. Mirshahi, A. Zarghami, M. Rajabnia and FF. Maternal knowledge and practice regarding childhood diarrhea and diet in Zahedan, Iran. Heal Scope. 2013;

5. Kemenkes RI. Profil Kesehatan Indonesia 2016. Profil Kesehatan Provinsi Bali. 2018. 1-220 p.

6. UNICEF. Childhood diseases. 2019.

7. Riset Kesehatan Dasar (Riskesdas). Badan Penelitian dan Pengembangan Kesehatan Kementerian RI tahun 2018. 2018;

8. Dinkes Provinsi Sumatera Utara. Laporan Kinerja Instansi Pemerintah Tahun 2018(Dinas kesehatan provinsi Sumatera Utara). 2018;140.

9. Kemenkes RI. Profil Data Kesehatan Indonesia. 2013;

10. Tambuwun, F. dkk. Hubungan Sanitasi Lingkungan Dengan Kejadian Diare Pada Anak Usia Sekolah Di Wilayah Kerja Puskesmas Bahu Manado. E- J Keperawatan. 2015;

11. WHO; Acceptable medical reasons for use of breast-milk substitutes. Who. 2018; kejadian diare akut pada balita usia 6-24 Bulan di Puskemas Sambas.

\section{SARAN}

1. Bagi petugas kesehatan perlu meningkatkan promosi kesehatan mengenai dampak ataua kibat dari pemberian MP-ASI dini kepada bayi yaitu sebelum bayi berusia 6 bulan yang ditujukan pada ibu hamil dan ibu menyusui sehingga memiliki pengetahuan yang baik mengenai ASI maka pemberian minuman maupun makanan tambahan (MP- ASI) tidak akan diberikan kepada bayi sebelum bayi berusia lebih dari 6 bulan.

2. Hasil penelitian diharapkan dapat menjadi bahan referensi khususnya yang berhubungan dengan makanan pendamping ASI (MP-ASI) dengan kejadian diare pada anak bayi.

12. Sheth $M$, Dwivedi R. Complementary foods associated diarrhea. Indian J Pediatr. 2006;73(1):61-4.

13. Hapilah YN. Program studi pendidikan dokter fakultas kedokteran universitas tanjungpura 2014. 2014;

14. Ningsih AN. Hubungan Pemberian ASI Eksklusif Dengan Kejadian Diare Pada Bayi Di Puskesmas Umbulharjo 1 Kota Yogyakarta Tahun 2016. Poltekkes Kemenkes Yogyakarta. 2017;16-22.

15. Andriana. Hubungan Pemberian Makanan Pendamping ASI Terhadap Kejadian Diare Pada Bayi Usia <6 bulan Di Desa Koto Tinggi Wilayah Kerja Puskesmas Rambah. Journal. 2010;

16. Sasongko A. Hubungan antara Pemberian MPASI dengan di Kecamatan Pedan Kabupaten. Sekol Tinggi Ilmu Kesehat 'Aisyiyah, Yogyakarta. 2012; 